This is an open access article licensed under the Creative Commons Attribution-NonCommercial 4.o International License (https://creativecommons.org/licenses/by-nc/4.0/)

Received: 13 May 2021 / Accepted: 16 June 2021 / Published: 8 July 2021

\title{
Overview of the Characteristics of the Albanian Organized Crime - Development Trends Over the Years
}

\author{
Ina Rama \\ Judge, Appeal Chamber, \\ Constitutional Court, Albania
}

DOI: https://doi.org/10.36941/mjss-2021-0032

\section{Abstract}

The paper aims to describe in general terms some features of the Albanian organized crime, considering its evolution over the years, either in terms of the way its groups are organized or in terms of the type and field of its activity. Regarding he content of the paper, by the term of the "Albanian organized crime" should be considered, the organizations of Albanian speaking groups, which cross the borders of the Albanian state and extend to other Albanian territories. They apparently, show similar characteristics and forms concerning their organization as that among the Albanians citizens. The first part of the paper describes the features of the Albanian organized crime based on the characteristics related to the nature and culture of the country or typologies that have accompanied the behavior of Albanians towards illegal activities and that have distinguished them from other groups within the same category. The paper emphases the idea of the important impact that has had the historical context in which the country has passed through, on the typology of this type of crime as well as, the influence of political and economic factors in the foundation and development of these criminal groups. The paper provides a description of the impact and importance of Albanian organized crime in the frame work of the organized crime that exists in Italy and in other countries of the region as well as, the impact that these groups have in relation to each other. In particular, the paper has addressed the typology and developments that have followed the Albanian organized crime over the years, in terms of criminal activity in the field of drug trafficking, providing data on the type of drugs that are cultivated and marketed in the country and also the role that this type of criminality has played in frame work of balkan route. The characteristics of organized crime in the area of arms trafficking are also addressed in a special way, reflecting some of its known features and specifics that comes as a result from consulting the open source data. The characteristics of organized crime are also summarized regarding the criminal activity carried out in the area of trafficking in human beings, especially those whose, as origin country is Albania. The paper closes with a citation of criminal activities which, although not yet dominant in the field of Albanian organized crime activity, have begun to be more and more present, becoming an important issue in the focus of foreign law enforcement agencies.

Keywords: organized crime, trafficking of narcotic drugs, arms trafficking, trafficking in human being, Albanian speaking citizens

\section{Characteristics of Criminal Activities and Organized Crime Groups}

Although having already entered the map of countries involved in criminal activity committed by organized crime, due to the existence of a decades-long totalitarian regime which prevented the massive spread of that phenomenon, Albania is found to have gained the status of an important grouping within the crime world which is especially known for its qualities and characteristics. 
According to various studies and the review of joint elements that over the years accompanied the typology of the criminal activity committed by Albania-based citizens, but also other ethnic Albanian citizens coming from Albanian-speaking territories, specific characteristics have been found for that category, differentiating it from other criminal groups operating in the same sector.

The following are the most common characteristics:

$>$ The main activity has always been trafficking of narcotic drugs;

$>$ Trafficking of arms and human beings occurs at considerably lower rates and levels of organization, mainly on an individual basis or unstable or not well-structured groups;

> Differently from the 1997 to 2004 period, when big criminal organizations with considerable territorial control operated, the strike of those organizations led to a new typology of organization;

> There has been a horizontal extension of the criminal groups that intensively collaborate with each other, by establishing criminal networks that also extend regionally or to Western Europe;

$>$ They are not known for their tight hierarchy or discipline since they operate and react to the personal characters that in most times dominate the nature of their individual conduct;

$>$ They appear quite flexible in the way of their operation, organization or collaboration, by mainly sticking to one kind of activity, but there have also been identified groups engaging into various kinds of criminal activities;

$>$ They operate by organizing themselves into solid nuclei in relatively small groups of four or five people and hire other temporary collaborators to satisfy the needs of the crime group's activities;

$>$ They maintain direct contact with other Balkan countries, mainly with crime groups of Albanian origin, but also non-Albanian groups (drug trafficking) for the purchase of narcotic drugs from them, mainly heroin, and then for its transport through Balkan routes, when not transiting to Italy and Greece by sea or land;

$>$ They have their contacts in Western countries with other groups that operate independently and autonomously or are extensions to the parent crime group, mainly engaged in finding access to markets; they are buyers or even make transport easier;

$>$ They massively make use of the domestic market to supply cannabis sativa, by being a producer country, but also engage in mainly finding heroin, but also cocaine, the latter at smaller quantities in case of lack of contacts or no eastward extension;

$>$ There have been reported various violence rates and it can no longer be concluded on a single easily identifiable characteristic;

$>$ They exert no obvious territorial control, given that they mainly target trafficking to other countries, but there is competition in access to markets;

$>$ The proceeds are mainly invested in Albania, in the form of immovable properties, commercial activities, luxury goods and so on, by also taking advantage of the high rate of the country's informal economy over the years. Commercial activities are often used to ease trafficking of narcotics.

What is more important is the size of economic dynamics that the Albanian organized crime is able to produce. According to some Transparency International annual reports, an estimated 8o percent of the Albanian economy has another parallel, i.e. for every Euro 100 of lawful investment, Euro 80 is unaccounted for, which is believed to mainly derive from organized crime, in a piece of information that indicates the level of representation, even at specific time periods and not on a constant basis, about the impact and size of inflows from illegal activities into the economy.

In case of drug trafficking, from a general perspective of globalization, traffickers appear to have been increasingly using political links in order to survive, mainly in the region where they carry out their activity, i.e. in the Balkans. In addition, there are reports about the use of important banks, mainly in Turkey or in the Western Balkans for the purpose of laundering money originating from trafficking. 
Researchers and international bodies attribute blood links as the axis of organization or even the strong bonds within the organization itself when describing the main trait of Albanian organized crime. That element makes them impervious to investigative infiltrations and destabilization due to competitive crime groups, thus giving them special power in the crime world. $(D N A)^{1}$

Recently according to DNA reports regarding the pugliese mafia, have resulted conclusions that: "The narcotics trafficking scenario continues to be heavily influenced by the closeness of Albania and the traffic of the narcotics from the Balkans. Regarding the relationship between the criminality of pugliese and the Albanian consortiums appears to be consolidated the main role taken by this ultimate, which tends to use and channels controlled by cosche pugliesi for the transport of narcotics also beyond the region". ${ }^{2}$

According to international reports, another important trait is the special skills to establish collaboration relationships on both ethnic and non-ethnic bases with other criminal organizations, be it locally or internally in committing a series of criminal activities, such as trafficking of narcotics and human beings, trafficking for the purposes of prostitution, as well as cybercrime. In this context, the Albanian criminals abroad display a very effective model of criminality that can be defined as "network crime" or a system relying on a network of illegal opportune relationships, with international profile management methods. (DNA)

According to periodic reports published by Italy's $D N A$, Albanian criminality continues to dominate in Italy, especially in the narcotics trafficking market when compared with other Balkan ethnicities operating there, signaling that Albanians groups have become aware that they represent an expanding criminal force, which is also indicated by the fact that there has been repeated use of violent clashes to dominate certain squares or areas, differently from the earlier employed gradual methods to enter local Italian markets.

Another strength of the Albanian organized crime, especially in drug trafficking, is the fact that Albanian crime groups are hegemonic in controlling the so-called "Balkan route", which serves to transit narcotic drugs destined for Western Europe.

According to annual reports published by Europol, Albanian crime groups have been recently transforming into multi-commodity (offering a diversity of products) and poly-criminal (criminal diversity) groups. They have diversified into various portfolios of criminal businesses, thus improving their ability to revamp in an ailing economy and strengthening their opportunities to explore new illegal markets.

Illegal activities such as the falsification of credit cards and especially multi-level falsification has been drawing the interest of those crime groups due to the low level of perceived risk.

Recently based on a join investigation team, in which have been involved the legal authorities of almost 10 different countries, and leaded to dismantling of one of Europe's most active Albanianspeaking networks trafficking cocaine into Europe ${ }^{3}$, Europol has noticed some new features of the typology of the Albanian organized crime. According to reports: for years, international importers of cocaine worked separately from the wholesalers and the gangs distributing the drug on the streets. In this case, the Albanian-speaking network under investigation ditched the entire model and controlled the whole chain - from arranging huge shipments directly from South America to the distribution throughout Europe $\mathrm{e}^{4}$.

According to reports by the U.S. Federal Bureau of Investigation (the FBI), Albanian organized crime activities in the U.S have been considerate within the Balkan organized crime. Referred to this description, Balkan TOC groups are politically and financially motivated groups influenced by,

\footnotetext{
${ }^{1}$ Direzione Nazionale Antimafia (DNA) - Italy's Anti-Mafia Investigation Directorate

${ }^{2}$ https://www.avvisopubblico.it/home/home/cosa-facciamo/informare/documenti-tematici/mafie/sintesi-della-relaz ione-della-direzione-investigativa-antimafia-secondo-semestre-2019/?hilite=\%27albania\%27

3 https://www.europol.europa.eu/newsroom/news/joint-investigation-team-leads-to-dismantling-of-one-of-europe

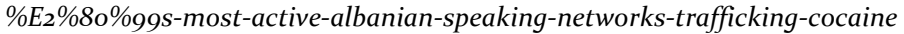

4 https://www.europol.europa.eu/newsroom/news/joint-investigation-team-leads-to-dismantling-of-one-of-europe $\% E_{2} \% 80 \% 99 s$-most-active-albanian-speaking-networks-trafficking-cocaine
} 
associated with, or originating from Albania, Bosnia-Herzegovina, Croatia, Kosovo, the Former Yugoslav Republic of Macedonia, Serbia and Montenegro, Bulgaria, Greece, and Romania. These organized crime groups cause significant financial harm to the United States each year.

Unlike traditional organized crime groups, Balkan groups do not appear to operate under a traditional hierarchy, but rather around ethnic associations and friendship ties. They also appear to be more agile, organic, and project-based. Balkan TOC groups are adept at adopting new technologies, thus increasing their ability to expand their criminal market base through cyberenabled fraud. These groups engage in a myriad of criminal activity including passport fraud, access device fraud, and identify theft, healthcare fraud, real estate fraud, insurance fraud, money laundering, drug trafficking, human smuggling, prostitution, and extortion. ${ }^{5}$

\section{Trafficking of Narcotic Drugs, their Characteristics}

Trafficking of narcotics is the main activity of Albanian organized crime, mainly focused on heroin and cannabis and, to a lower degree on cocaine. Albania mostly serves as a transit country rather than the final destination, but there has also been an increase in the number of local drug users and, as a result, the establishment of organized networks of drug dealing in the country's main cities.

Europol reports deem that the criminal activity involving Albanian-speaking criminals in drug trafficking to the EU is dominant, the same as the role played by the "Balkan route" in this context. Foreign researchers report that 70 percent to 80 percent of the transit of heroin entering Western Europe is enabled by Albanian-speaking criminals in collaboration with Turkish criminal groups.

The "Balkan route" displays a high level of diversity and flexibility. Deliveries of heroin cross the Adriatic before transiting through Greece and continuing to Romania and Bulgaria across Central Europe or such deliveries enter the Western Balkans which for many years served as a key hub for their transportation. Albania, North Macedonia and Kosovo are mostly countries used for warehousing and repackaging. Kosovo is also considered a zone serving Albanian-speaking criminals as a trafficking basis. Turks and Albanian-speaking criminals continue to dominate heroin trafficking within EU countries. In the whole of Europe, there is a clear dynamic relationship between criminal centers and heroin routes, with Italy remaining a key locality due to the coastal border, air and maritime transport infrastructure and being a central and concentrating basis for criminal groups. The vicinity of the northeast criminal center to the Russian Federation and collaboration between Lithuania and Albanian-speaking rings has facilitated trafficking from Central Asia to Western Europe. ${ }^{6}$

It appears that transport is mainly organized by Albanian crime groups themselves, but there has also been an increase in foreigners being caught in Albania's border checkpoints, mainly Greeks, Italians and North Macedonians. When analyzing reports by law enforcement agencies, it seems that the heroin supply contacts are ethnic Albanians across the border (holding North Macedonian citizenship) or Turks who possess quantities of heroin. After reaching Albanian territory, narcotic drugs is sold to other crime groups or is exported to Western and Central Europe or to Greece.

As of 2006, there has been frequent use of the Strait of Otranto or even the coastal border with Greece by using speedboats, but subsequent tough measures by imposing a ban on such vessels led to switch to land use, mainly to Montenegro and Kosovo before further continuing northwards to Slovenia. The Kosovo-Albania northeaster border area is a zone reported to be heavily engaged in heroin and cannabis sativa trafficking across that route. Nevertheless, the use of the maritime border to carry out exports has continued, but this time through concealment in transport vessels, for a certain time period being dominated by a rising number of speedboats/inflatable boats coming from Greece and mainly loaded with cannabis in Albania's southern coastline. The import of heroin is mainly carried out by road transportation vehicles such as trucks or passenger cars, recently with a

\footnotetext{
${ }^{5}$ https://www.fbi.gov/investigate/organized-crime

${ }^{6}$ https://www.unodc.org/documents/wdr/WDR_2010/World_Drug_Report_2010_lo-res.pdf 
slight rising tendency of trafficking routes switching under the control of the most powerful crime groups. In some cases, the Albanian organized crime groups transport heroin by avoiding Albanian territory and instead use North Macedonia, Kosovo and Montenegro to transit the heroin. There is no clear information about the scale of the phenomenon and details about the level of organization.

A considerable part of the Albanian organized crime activity is carried out in Italy and according to reports by Italy's $D N A$, Albanians rank first when it comes to the number of people investigated into compared with other Balkan citizens, accounting for 89 of such investigations over the years.

Albanians have mainly been investigated into "associazione per delinquere" (Unlawful association to commit a crime) for the purpose of trafficking narcotics. All DDA offices (DDA-Italian acronym for "Anti-Mafia District Directorate") have registered at least one case against Albanian citizens, in a fact indicating the spread of their activity all over Italian territory. However, Albanians are mainly based in Florence, Milan, Perugia and Ancona.

It is quite rare for Balkan citizens (including Albanians) to be investigated into organized crime activity in areas which have been traditionally controlled by the Mafia. Only sporadic individual investigations are registered in such cases. The Milan, Florence and Perugia DDA offices have registered the biggest number of cases against Albanian citizens, in a circumstance deriving from the fact that Northern Italy areas, due to their high standard of living and being important economic centers, also serve as the most appropriate sites for the Albanian organized crime groups to carry out their illegal activity.

Italian judicial authorities have considered of key importance the entry into force on August 1, 2011 of the agreement on International Judicial Cooperation between Italy and Albania, the absence of which had led to a situation of impunity for Albanian citizens who had committed offences in Italy and had come back to live in Albania, thus avoiding the investigation into them or serving their sentences. Another problem currently identified by the Italian criminal police is related to the possibility of Albanian citizens changing their names and surnames quite easily and with no limitations. Those citizens may possess several identification documents, all of which are lawful and valid. No specific limit has been set for the number of times a citizen may change their name/surname and that element seems to have led to issues with respect to the identification of those citizens.

To the Albanian organized crime, trafficking of narcotics is the primary sector. Albanian organized crime groups control the heroin coming from Turkey and Afghanistan, by removing it from the transition zone and taking it to European markets, in addition to controlling the massive spread in recent years of the cannabis sativa trafficking, triggered due to an increase in cannabis cultivation in Albania.

In addition, the Albanian organized crime has gained an important role even in the trafficking of cocaine coming from South America, which reaches Europe hidden in containers via the northern ports.

The typology of crimes committed by Albanian citizens, but also other Albanian-speaking citizens has become subject to analysis and reports by Europol, the EU's law enforcement agency. According to Europol data and analyses, Albanian-speaking criminal groups play a significant role in supplying Albania and Kosovo-grown cannabis to Southeast Europe, which is later delivered to Greece, Italy, Slovenia, Hungary and also in Turkey, where it is swapped with heroin.

Europe's northwest criminal center plays an important role in the distribution of cocaine to EU markets. The cocaine is warehoused there and transits through that center to the U.K. France, Italy, Spain, Hungary, Nordic countries and the Russian Federation. In itself, that way of trafficking is proof of the diversity of the routes that are used and the dynamics of relationships between criminal networks and crime centers, at a time when cocaine is more and more entering the EU via Balkan routes.

Supplies to Albanian-speaking criminal groups in Southeast Europe are also carried out from The Netherlands. As a rule, that draws attention due to the form of drug trafficking being a combination of skills, criminal logistics and infrastructure. The use of Western Balkans as a center of 
heroin trafficking has in fact also determined the need for setting up in those areas criminal logistics which is also being used for cocaine trafficking. For example, cocaine in cargo containers transiting through south and southeastern Europe stop at Montenegro ports to get back to EU markets. Even the Albanian organized crime has its say in this process, and is reported to have been constantly getting involved even in cocaine trafficking.

In Albania, cocaine has mainly entered in small quantities through postal packs, but also via commercial deliveries, hidden in cargo containers coming from South America. In recent years, there has been an increase in the identification of local cases, indicating of a trend of using Albanian territory as a transit point for penetration to Western markets. Of course, a portion of it is destined for the local Albanian market where there has been rising demand by users.

According to the International Narcotics Control Strategy Report, an annual report by the U.S. Department of State, Albania is a transit and destination country for cannabis, heroin and cocaine. Albania is a source country for cannabis destined for EU countries. The Albanian authorities have significantly intensified efforts to seize drugs and arrest perpetrators from 2012 onwards. The increase in marijuana seizures also indicates the significant rise in domestic production, but, with the exception of cannabis, Albania is not a significant producer of any illegal drugs, such as precursor chemicals or synthetic drugs ${ }^{7}$.

According to those reports, the activity of Albanian organized crime is influential and present in the following countries:

$>$ Croatia: That is despite this country having a tough institutional and legal framework to control and destroy organized crime engaging in trafficking and corruption. Europol has warned that even though Turkish organized crime groups dominate heroin trafficking to and within the EU, the influence of Albanian ethnic crime groups has increased in Croatia.

$>$ Switzerland: According to the Swiss Federal Police, there exist three kinds of organized ${ }^{8}$ crime groups in Switzerland - the West Africa networks involved in cocaine trafficking; the Albanian gangs dealing with heroine and prostitution and money laundering; and employment networks from former Soviet Union republics. ${ }^{9}$

$>$ Bosnia and Herzegovina: while most drugs entering this country are trafficked to other destinations, mainly to Western Europe, local or regional organized crime groups have been engaged in the local distribution of narcotics for an estimated 105,000 local drug users in Bosnia and Herzegovina. That is proof of the ties and conflicts among elements of organized crime in Bosnia and Herzegovina, Albania, Serbia, Montenegro, Croatia, Austria, Germany, Italy and South America at an increasing rate. ${ }^{10}$

$>$ Most of the heroin entering Italy has been transited through Greece, Turkey and Albania. Italian law enforcement agencies with liaison offices based in Turkey, Iran, Afghanistan and Uzbekistan aimed at helping their foreign counterparts halt the transport of narcotics from source areas to destined areas in Italy. The most obviously involved foreigners in criminal offences related to heroin trafficking within Italy include Tunisians, Moroccans, Albanians, Nigerians and Algerians. The import of hashish to Italy continues to mostly originate from Morocco and is delivered through Spain, but also originates from the Middle East with Albania and Montenegro being the key transit countries. ${ }^{11}$

The following are the top organized crime groups dealing with drug trafficking, with constant reported participation of Albanian criminal groups:

$>$ Cocaine: Ndrangehta, Camorra, Albanian, Colombian, Dominican, Moroccan and Spanish groups;

\footnotetext{
${ }^{7}$ https://2009-2017.state.gov/j/inl/rls/nrcrpt/2013/vol1/204048.htm\#Albania

${ }^{8}$ https://2009-2017.state.gov/j/inl/rls/nrcrpt/2011/vol1/15636o.htm\#croatia

${ }^{9}$ https://2009-2017.state.gov/j/inl/rls/nrcrpt/2011/vol1/156363.htm\#switzerland

${ }^{10}$ https://2009-2017.state.gov/j/inl/rls/nrcrpt/2011/vol1/156359.htm\#bosniaandherzegovina

${ }^{11}$ https://2009-2017.state.gov/j/inl/rls/nrcrpt/2011/vol1/156361.htm\#italy
} 
$>$ Heroin: Sicilian, Apulian and Albanian-speaking groups, Tunisian and Moroccan groups.

$>$ Cannabis: Lazio, Apulian, Sicilian, Moroccan, Tunisian, Spanish and Albanian groups ${ }^{12}$.

North Macedonia is part of the Balkan route that is used to supply Afghan heroin to Western Europe. The Albania produced hashish and marijuana also crosses through North Macedonia to reach Turkey and Greece. In Serbia, Turkey and Montenegro, there is also reported Albanian organized crime activity mainly involving marijuana trafficking to those countries.

\section{Arms Trafficking}

Although according to statistics by Albania's prosecution, there is a relatively low number of cases over the years related to arms trafficking, the situation appears differently when referring to international bodies.

According to information on cases investigated into by the Albanian prosecution, arms trafficking in Albania has mainly involved small caliber arms such as handguns coming from Kosovo and Montenegro. It is suspected that there have been imports of explosive materials from Montenegro and a trend of arms or ammunition exports to those countries or even Greece. The amounts of trafficked arms identified following investigations have been relatively low and the involved groups are mainly unstable, with few members and with their financial capacity at not significant levels. The registration of arms trafficking cases has been inconsistent over the years, but yet at a limited and insignificant number of cases, when taking into consideration information related to the commission of this kind of criminal activity.

According to Europol, EU member countries continue to remain affected by arms trafficked from the Western Balkans. The huge amounts of arms and ammunition from the 1990s armed conflicts remain out of the authorities' control and continue to be used to supply international criminal networks, including the huge illegal stockpiles in Albania.

The trafficking is carried out by big international networks, generally linked to trafficking in human beings and drug trafficking. Italian organized crime groups such as Ndrangheta and Albanianspeaking groups are also considered to have been traditionally involved in the illegal arms trade by using routes mostly similar to the ones established to traffic drugs.

\section{Trafficking In Human Beings}

According to reports by the Office to Monitor and Combat Trafficking in Persons, a U.S. Department of State agency, Albania has been a source country for men, women and child victims of sex trafficking and forced labor. Albanian victims face sex trafficking within Albania and to Greece, Italy, North Macedonia, Kosovo, Belgium, The Netherlands, Germany, Switzerland, Ireland and the United Kingdom. Lots of women are subject to trafficking after accepting offers to work in coffee bars, night clubs in neighboring countries, especially in Kosovo, Greece and Macedonia. Labor trafficking victims from the Philippines have also been identified in Albania. Albanian children are subdued into begging and other forms of forced labor. In some cases, Albanian women are subdued into sex trafficking or forced labor following arranged marriages ${ }^{13}$.

According to statistics by the Albanian prosecution, there has been a considerable drop in cases compared to the 1990 or or the early 2ooos. The new recruitment typology mainly relies on fraud or even deals with women already engaged in prostitution within the territory or by taking advantage of the victims' weak social status. Over the years, what emerged as a new characteristic of this kind of criminality was the fact of the emergence of a new destination such as Kosovo where women are employed as dancers in night clubs and forced into prostitution.

The exploitation of lots of Albanian women outside the territory of the Republic of Albania

\footnotetext{
${ }^{12}$ https://2009-2017.state.gov/j/inl/rls/nrcrpt/2012/vol1/184100.htm\#Italy

${ }^{13}$ https://2009-2017.state.gov/documents/organization/210738.pdf 
appears to continue, but mainly involves earlier recruited women. New recruitments are not excluded, but due to the nature of this kind of crime, there is no real time reporting. There is no information about organized forms or groups in the recruitment or transportation stages, however the occurrence of such forms is not excluded in destination countries such as Kosovo, where a network of night clubs exploiting young women appears to have existed by maintaining contacts with Albanian citizens. Organized forms of recruiting women could also be present in Albanian territory, but no official data are reported in this respect.

According to a Europol report, Albanian organized crime is described as a grouping involved in each of the consecutive stages of illegal migration from the source to destination countries. This kind of migration is also linked to potential trafficking in human beings by Western Balkans organized crime groups. According to Europol, there has been a growing trend in the number of women involved in trafficking, with a key role, especially in recruiting, transferring, subduing and supervising victims. Such a tendency is noticed among all ethnic groups engaged in trafficking. Europol reports show that although traffickers have significantly reduced acts of violence against their victims, this practice appears to have had no influence on Albanian organized crime whose members continue to use violence in order to fully subdue the recruited women. Other traffickers have attempted to give another picture of this kind of criminality by avoiding their dominant position and handling their role as service providers or mediators between victims and customers, but this kind of typology is not found to be part of the overall picture.

\section{Various Crimes}

According to Europol reports, organized crime groups from the Western Balkans, Southeast Europe and the former Soviet Union have been reported to increasingly engage in acts of property crimes in EU member countries, where the scale of violence used is significant. Committed crimes range from organized car thefts, counterfeiting banknotes and even armed robberies. Reports show that Albanian-speaking criminals are known for using extreme violence, including against theft victims. Many group members are considered to have a background as former intelligence service or police officers or even paramilitaries, with those elements remaining part of their character, despite changes over the years in the typology of criminal activity.

\section{References}

Annual reports of the General Prosecutor on the crime situation in Albania

Annual International Narcotics Control Strategy Reports, published by the U.S. Department of State

Agreement between the Republic of Albania and the Republic of Italy approved by law no.9871, date 11.2.2008, in addition to the European Convention on Extradition of 13 December 1957 and the European Convention on Legal Aid in Criminal Matters of 20 April 1959. ${ }^{14}$

Annual reports published by Transparency International

Periodic reports published by Direzione Nazionale Antimafia, Italy

Annual reports published by Europol

Annual reports published by the Office to Monitor and Combat Trafficking in Persons of U.S. Department of State.

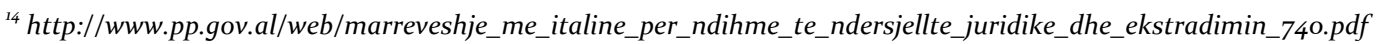

